\title{
Improving Tectonic Geomorphology Analysis and Interpretation of River Mobility Utilizing LiDAR-derived DEMs
}

\author{
Saied Pirasteh* \\ Department of Geography and Environmental Management, University of Waterloo, Canada
}

Received: 阱 March 14, 2018; Published: 眥 March 23, 2018

*Corresponding author: Saied Pirasteh, Department of Geography and Environmental Management, Faculty of Environment, University of Waterloo, Environment 1-401A, 200 University Avenue West, Waterloo, Ontario, N2L 3G1 Canada, Tel: 416-835-5930;

Email: s2pirast@uwaterloo.ca

\begin{abstract}
This study contributed a reliability of Light Detection and Ranging (LiDAR) techniques to investigate tectonic geomorphology analysis of river mobility with high resolution Digital Elevation Models (DEMs). This study interpreted the impact of tectonic geomorphology on landslides occurrence in a rugged topography. In this study, river responses were investigated by using an integration of LiDAR, geomorphology, and a field survey to determine the tectonic geomorphology signatures. The study reveals that the Zagros Folded Belt (ZFB) of Iran with the rugged topography and vegetated area is susceptible to landslides associated with the Dez River in north of Khuzestan Province wherein the Khuzestan Plains the river systems were found to be mobile and able to respond, both laterally and vertically, to the active tectonics.
\end{abstract}

Keywords: LiDAR; Zagros mountains; DEM; River mobility; Geomorphology; Hazards

\section{Introduction}

TheZagros Mountains in Iran are greatly influenced by structural geology, tectonics, and bedrock lithology, and the courses of major rivers (Karun River and Dez River). The geomorphology of major rivers develops, at least partly, in response to a number of different external controls. For the time-scale of the Late Quaternary, key external forcing factors affecting the form of major rivers that have been recognized, including neo-tectonics, $[1,2])$, especially in the Zagros Mountains which have extensive neo-tectonics [3-5]. The Zagros Mountains are one of the youngest and best exposed foldthrust belts of the Alpine-Himalayan orogenic system. The Zagros Orogen trends roughly NW-SE and can be subdivided into four major NW-SE trending zones. At fine scales, the river courses are variable with similar river reaches in similar tectonic scenarios apparently having different responses; diverting around uplifting areas where landslide hazards are suspected in some instances and cutting across them in others. In the Zagros Mountains (Iran) landslides mechanism associates with complex geological-geomorphological activities that have created an immature and rugged landscape and imposes landslide hazards. A high slope influences the stability of the region, particularly, with high tectonic activity. Also, the presence of active faults and sometimes earthquakes are triggering landslides in this region.

Major rivers are complex systems with complex responses (both spatially and temporally), and studies often encounter difficulties in determining causes for observed changes in a river, even when parameters can be carefully controlled. One approach is to investigate the changes possibly impacted by the main key external factors using LiDAR remote sensing techniques and integrating them with spatial data and field observations. With such an approach it may be possible to collect detailed information and to improve and elucidate certain characteristics of the rivers Karun (Figure 1A) and Dez (Figure 1B) that are influenced more by tectonic geomorphology and specific external factors.

The River Karun is the largest and one of the longest rivers of Iran. It crosses the Zagros Mountains in the south-west and flows into the Persian Gulf. The River Dez is also one of the rivers which crosses the Zagros Orogen and, after passing the city of Dezful, joins 
the Karun River. The rivers Karun and Dez have good potential for investigating the influences of external forcing factors on major rivers in a semi-arid foreland basin setting. The River Karun (Figure 1) and some parts of the River Dez flow through lowland south- west Iran. The River Karun is a major river, being about $890 \mathrm{~km}$ long, with a drainage catchment area of slightly greater than 60,000 $\mathrm{km} 2$ and a mean water discharge at Ahwaz of about $575 \mathrm{~m}^{3} \mathrm{~s}^{-1}[6]$.



Figure 1: (A) Google Earth satellite image showing sthe River Karun near to Ahwaz city, Iran. (B) Google Earth satellite image showing the River Dez in Dezful city, Iran.

Satellite remote sensing and photo grammetry techniques have limitations in data accuracy and generating of a high-resolution of DEM as compared to the LiDAR techniques. Because in satellite surveying images elevation grid is the tops of buildings and top of tree canopy. For example, orthophoto WorldView2 from the Digital Globe at https://data.photosat.ca/ provides DEM with $1 \mathrm{~m}$ relative elevation accuracy.

LiDAR is an advanced technique and can provide a good set of three-dimensional data with $\mathrm{x}, \mathrm{y}$ and $\mathrm{z}$ axis to generate a DEM, as well as other information such as intensity, color, geologic and geomorphic using DEM's derivatives to study and assess landslides prone areas. These techniques can provide millions of data measurements, in a few minutes that are commonly denoted as "3D Point Clouds". Compared to traditional surveying techniques, LiDAR technology shows a great potential for hazards and geomorphology of river mobility. These methods have been emerging as a hot and attractive research topic. It is because; LiDAR can capture the data very fast with high data density, 3D object representation, as well as user-friendly operation. Particularly, the high-density 3D points captured by LiDAR can provide a chance to identify the detailed and distinctive tectonic geomorphology of river mobility characteristics in partial areas, and to enhance interpretation of landslides study [7]. LiDAR systems and geological-geomorphological hazards have been reviewed and discussed in Lohani \& Mason [8]; Wehr \& Lohr [9]; Baltsavias [10]; Lohani \& Singh [11]; Pirasteh \& Li [12]; Pirasteh et al. [13]. A clear reference to an updated discussion is commented in Shan and Toth [14] book. Finally, a brief review of LiDAR (and other remote sensing techniques) utilized in landslide studies and tectonic geomorphology of river mobility is found in Prokop and Panholzer [15], and Safe Land Deliverable 4.1 [16].
This study investigates:

a) How tectonic signatures influence the Dez and Karun rivers.

b) Where a river course crosses smaller tectonic features, such as lineaments and concealed faults,

c) Where a river cuts directly across an anticline.

d) Where a river course follows a structural feature,

e) understanding the tectonic activities and their behavior from river course changes,

f) Landslides potential areas in the ZSB, where high tectonic activities have influenced geomorphology and the Dez River.

\section{Study Area}

The study area covers the Zagros Mountains in the provinces of Khuzestan and Lorestan in SW Iran. Ahwaz, Shushtar, Dezful, Gotvand, Pole-Dokhtar, and Khorramabad are cities in the main study area (Figure 2) in Khuzestan province. In this main study area, the Karun River is mostly a meandering or semi-braided river, with some anomalous near-straight reaches. The Dez River passes through Dezful after the crossing Zagros Fold Belt (ZSB) in Lorestan province with its variable geology and geomorphology. The study follows the flow of the Karun and Dez rivers and covers $33^{\circ} 28^{\prime} 24^{\prime \prime}$ $\mathrm{N}-31^{\circ} 9^{\prime} 19^{\prime \prime} \mathrm{N}$ and $48^{\circ} 23^{\prime} 53^{\prime \prime} \mathrm{E}-48^{\circ} 30^{\prime} 5^{\prime \prime} \mathrm{E}$, an area which varies in elevation from $41 \mathrm{ft}$ to $4700 \mathrm{ft}$. Dry farming and irrigation farming is extensively practiced in the region, and the temperature varies from about -3 degree to +52 degrees Centigrade. 


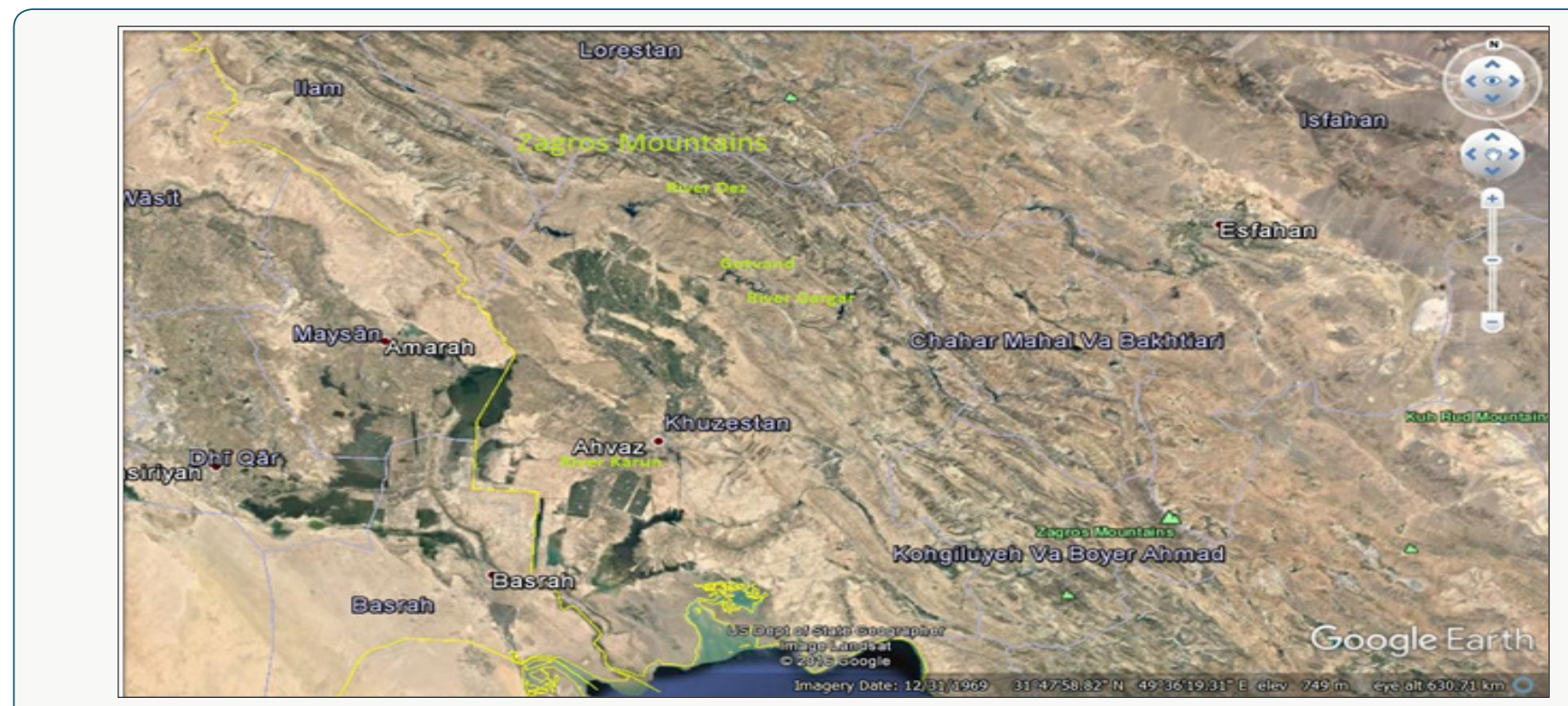

Figure 2: Study area.

\section{Geology}

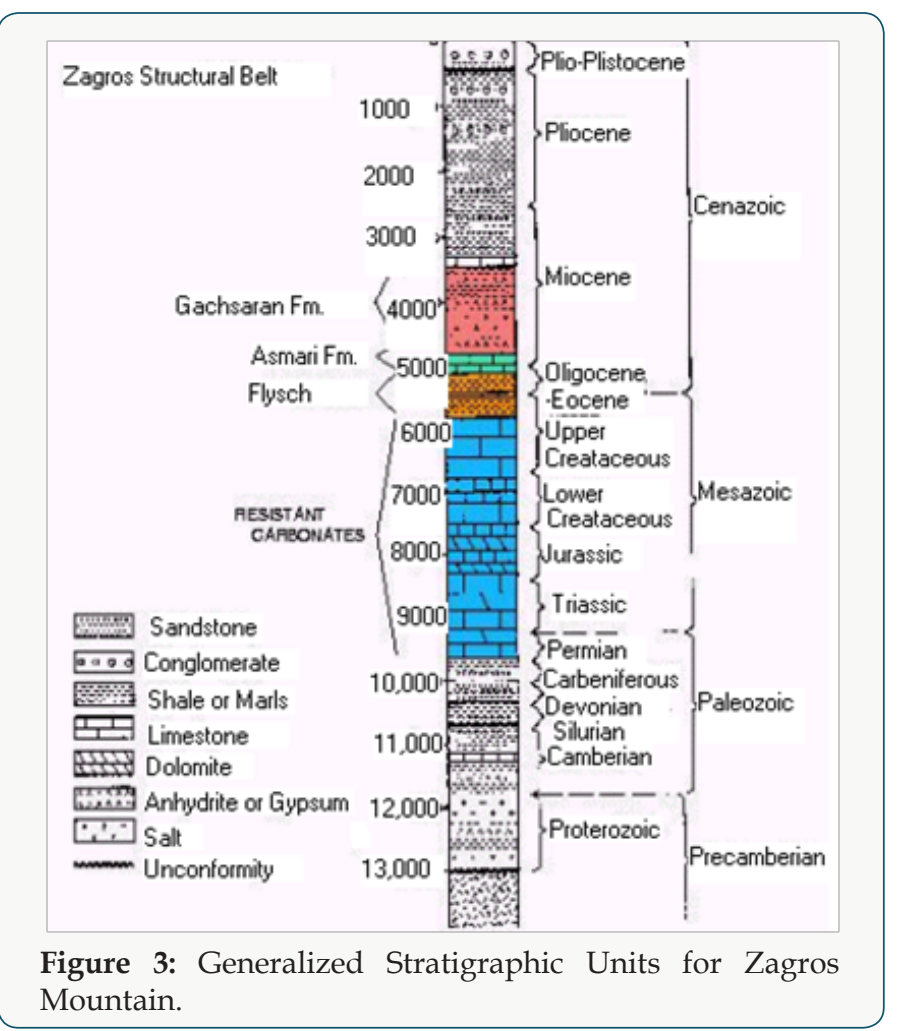

The geology of the Zagros Mountains fold-thrust belt is well exposed and was studied by Stocklin [17] and many other researchers such as Falcon [18], Colman-Sadd [19], and Pirasteh and Ali [20]. They divided the Zagros Mountain into four units: a) Sanandaj-Sirjan Zone, b) Imbricate Zone, c) Zagros Fold Belt, and d) Molasse Cover Sequence. They have different characteristics because each of them has distinct geological, geomorphological, and geophysical signatures. Colman-Sadd [19] generalized Stratigraphic column (Cretaceous to Miocene) of the ZSB into four units based on the relative resistance to erosion (Figure 3). Stratigraphically, the study area mainly covers the Zagros Fold Belt (ZFB), which consists of different lithological units ranging in age from Miocene to Subrecent and Recent. The area is mostly dominated by sandstone, shale, dolomite, limestone, silt, red and gray marls, gypsum, conglomerates and recent alluvium.

\section{Structural Geology and Tectonic Geomorphology}

The tectonic force has considered as an impulsive event that occurs at the beginning of the geomorphic cycle. This tectonic force may result in river mobility and triggering landslides in some parts of the Zagros Mountains. Subsequently, geomorphic process attacks and degrades the topography. Since tectonic activities in the area started during Triassic to Late Cretaceous, the oldest geomorphic features have formed in the Zagros Mountains, and these have resulted in a rugged topography. Lowland south-west Iran, including the Khuzestan Plains, is a foreland basin tectonic setting formed by the collision between the Arabian Plate and the Iranian Plate. During the Cenozoic, the Arabian Plate has spread towards the Iranian Plate with the opening of the Red Sea and the Gulf of Aden, and has rotated anticlockwise around a pole in the eastern Mediterranean [21].

This study stressed that in the south-west Iran the movement of the Arabian Plate had been approximately NNE. It is resulting in closure, obduction and subduction of the Neo-Tethys beneath the Iranian Plate from about the Late Cretaceous (c.100 Ma) on wards, and the formation of the roughly NW-SE trending Zagros fold mountain from about the Miocene (c.16 Ma) onwards. However, the details of the collision are complex and have been accounted for by a number of different models $[3,22,23]$. Whilst the details of the sub-surface structural geology may be unresolved, the scenario at the surface using fieldwork (Figure 4) and remotely sensed data (Figure 5) is fairly clear. 




Figure 4: Geological examples of anticlines folds and major faults in study area: Anticlines: 1. Aghajari 2. Marun 3. Yekmahe 4. Mishdaq Faults.

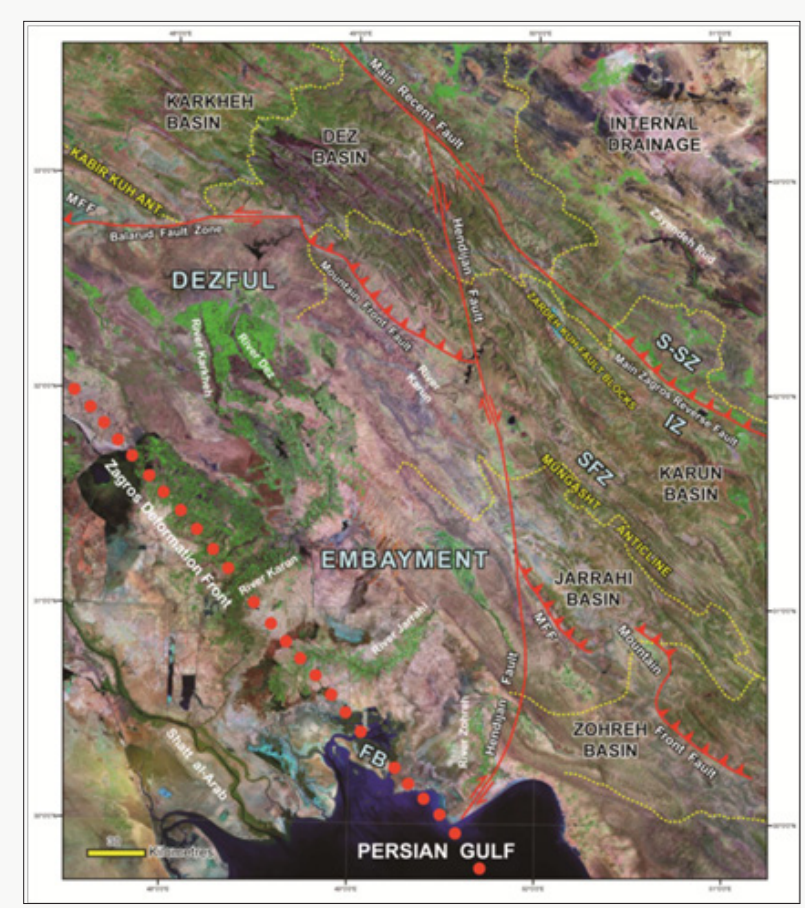

Figure 5: Structural features, tectonics, and geomorphology of the study area in Lorestan and Khuzestan provinces.

MFF Mountain Front Fault

Structural zones:

S-SZ Sanandaj-Sirjan (or metamorphic) Zone

IZ Imbricated Zone (or High Zagros)

SFZ Simple Folded Zone

FB Foredeep of the Mesopotamian-Persian Gulf Foreland Basin.

The main structural unit over which the River Karun flows in south-west Iran is the Dezful Embayment. The structural geology map (Figure 6) of the Zagros Mountains indicates the tectonic activities in the area. The origin and nature of the embayment has been much debated, but, in simple terms, it is an area of subdued relief and subdued exhumation, compared with the zones immediately to its north-west and south-east [21]. The main tectonic features affecting the River Karun in lowland south-west Iran are the roughly NW-SE trending anticlinal folds.



Figure 6: Structural geology map of the Zagros Fold Belt (ZFB). It is showing density of the lineaments and probability potential of landslides.

\section{MFF Mountain front fault}

\section{Structural zones:}

a. S-SZ Sanandaj-Sirjan (or metamorphic) Zone

b. IZ Imbricated Zone (or High Zagros)

c. SFZ Simple Folded Zone 
d. FB Foredeep of the Mesopotamian-Persian Gulf Foreland Basin.

A zone of rapid rock uplift may have a steeper gradient, higher relief, and higher gradient indices (Burbank and Anderson [24]). To emphasise the tectonic signatures, to better understand the tectonics of the study area, and to highlight where a river course crosses smaller tectonic features, such as lineaments, concealed faults, or anticlines, the stream gradients of the Dez and Karun river profiles were drawn digitally on the LiDAR-derive DEMs with a high-resolution (5m) in pixel.

\section{The river dez}

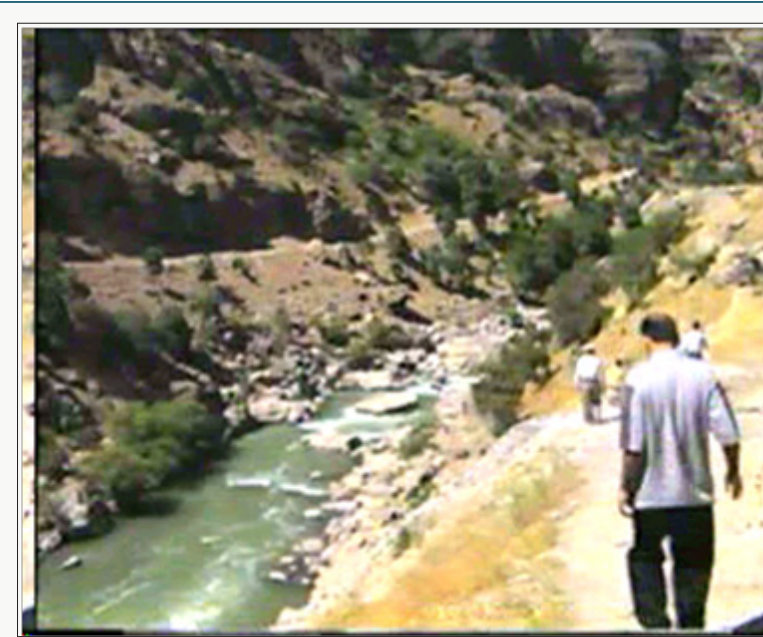

Figure 7: Field photograph of the Shahbazan Fault, with the Dez River following the fault.

The River Dez (Figure 7) is a river of the Zagros Mountains that has been influenced by the neo-tectonic activities in the area and which one tries to change the landscape of the Zagros Mountains. This area has experienced a number of low to high magnitude of landslides because of tectonic activities. A high density of lineaments in the study area has been determined and interpreted as low to high tectonic and landslide prone areas. Tectonic activities generate erosion and sedimentation in the Zagros Fold Belt. This influences landslides occurrence as well as mobility of the river.
The Dez River (Figure 8) follows structural features like folds and faults in the area (Figure 4). Thus, where the lineaments mostly dominated, the pattern of the direction of the Dez River could be easily seen.

LiDAR-derived DEM (5m) and River Tools software allow us to draw the Dez River profile from Chalanchoolan police station near Brojerd city southwards to include the Sanandaj-Sirjan Zone, Imbricate Zone, and Zagros Fold Belt (ZFB). The total length of the river along the profile is approximately $165 \mathrm{~km}$ (Figures 8 $\&$ 9). The profile has been divided into three parts: (1) The high Zagros (Imbricate Zone), (2) the folded Zagros, and (3) the folded Zagros toward Dezful city. A step-like river profile of the study area is predicted to approach a graded profile, indicating that area has been tectonically disturbed. This study interpreted that these areas have most likely potential to landslides whiles it influences mobility of the river. The stream gradient indices deduced in each part of the profile, showed variation from $806 \mathrm{~m}$ to about $142 \mathrm{~m}$ per kilometer, meaning that the river profile is experiencing varying tectonic activity and bedrock erosion resistance. This interprets that the river mobility and landslides occurrence vary from location to location in the whole study area.

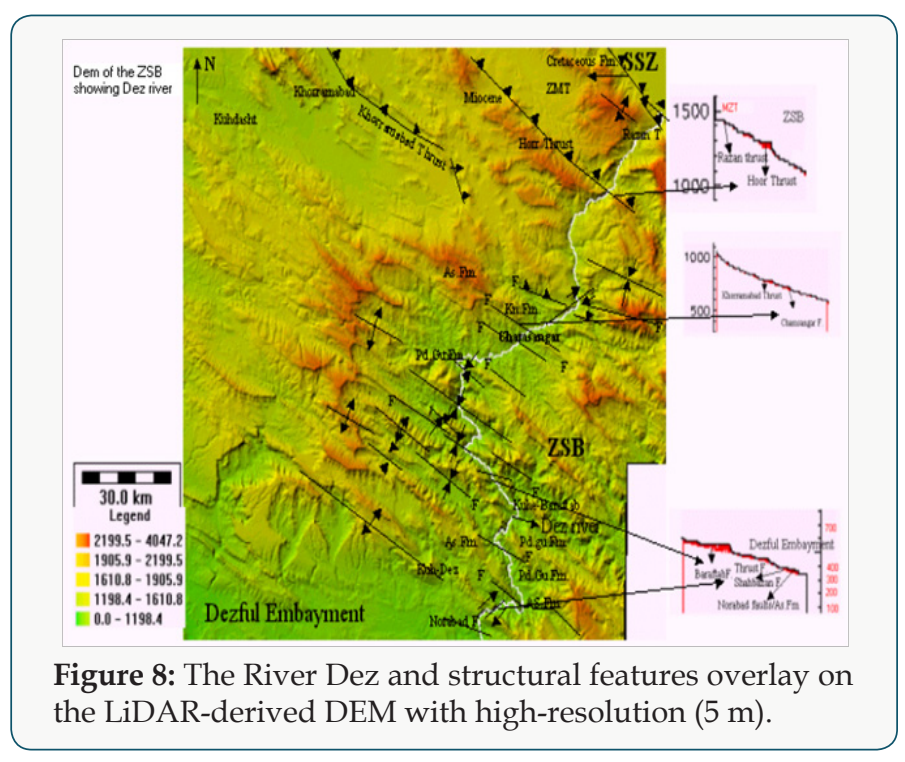

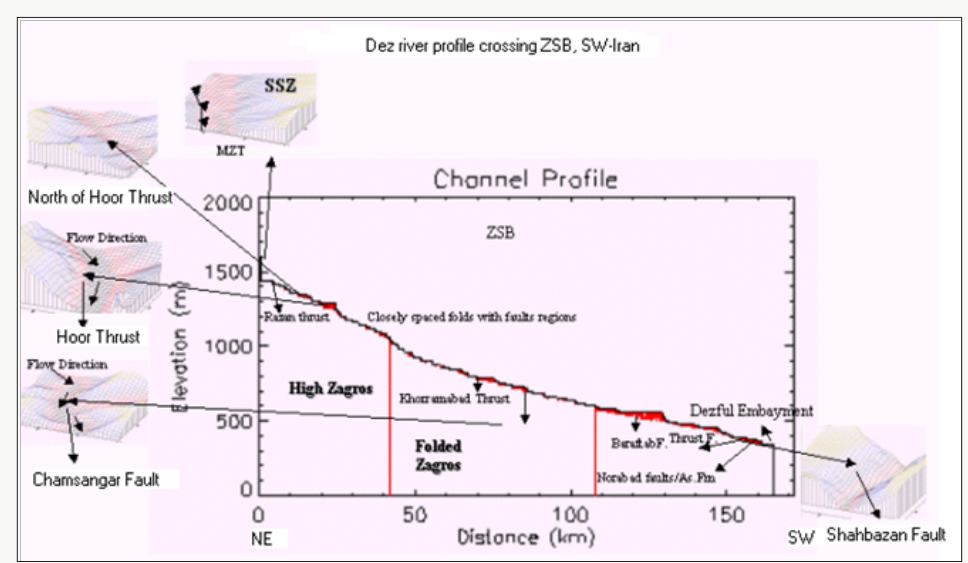

Figure 9: The River Dez profile along about 165 km. 


\section{The river karun}

The highest discharge river in Iran is Karun River. It rises in the Zard Kuh Mountains of the Bakhtiyari district in the Zagros range, and then receives many tributaries, such as the Dez and the Kuhrang, before passing through the capital of the Khuzestan province of Iran, the city of Ahvaz. The Karun River flows to the Persian Gulf, and forking into two primary branches on its delta. They are: the Bahmanshir and the Haffar that joins the Arvand River (Shatt al-Arab in Arabic), emptying into the Persian Gulf. The important Island of Abadan is located between these two branches of the Karun. The port city of Khorramshahr is divided from the Island of Abadan by the Haffar branch.
The Karun River profile (Figure 10) is drawn from north of the Gotvand dam in the Zagros Folded Belt (ZFB) out into the Khuzestan Plains. The profile divided into two parts. The north part of the profile with high elevation and topography indicated that sudden changes in topography are probably influenced by tectonic activities. Field data (Figure 11) is combined with the profile to improve understanding of the effects of tectonics on changes to the river system, including possible river migration. A slightly step-like Karun River profile to the north of the Gotvand dam is predicted to approach a roughly graded profile. Topography is changing the direction of the Karun River.



Figure 10: River profile overlaid on the LiDAR-derived DEM with high-resolution $(5 \mathrm{~m})$.

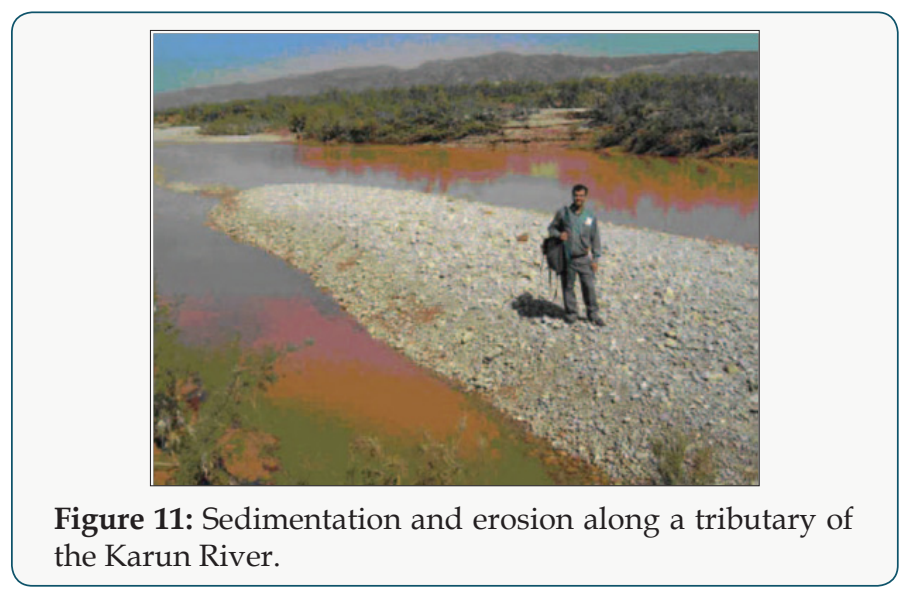

Sedimentation and erosion with weathering mostly appears in the southern part of the profile and indicates that changes in the Karun River have been affected by the tectonics of the north and the erosion and subsequent deposition of sediments in the lowlands of the study area. This produced changes in the course of the Karun River and the development of geomorphologic features, such as meanders.

\section{Methodologies}

Extensive fieldwork, including geology, tectonic and geomorphological description, and basic topographic survey of rivers and river terraces by using trestrial laser scanning (TLS), was undertaken and incorporated into the LiDAR-derived DEMs (5m). The Landsat ETM+ was geometrically registered on the basis of digital topographic maps of 1:25000 scale of the Iranian Survey
Organization (ISO) by using ENVI software. The LiDAR point clouds in LAS format were collected to generate DEMs. The ArcGIS 10.2 was used to extract the Triangulation Irregular Network (TIN) and DEMs of the study area. The filtering process was applied to the LAS data to remove the noise including vegetation

\section{Processing of ALS Data}

A high-resolution DEM is the raster representation, in which each grid cell records the elevation of the earth's surface, and reflects a view of terrain as a field of elevation values. In this study, a resolution of 5 meters in the pixel was applied for grids to generate the high-resolution DEM. Airborne Laser Scanning (ALS) point clouds data in LAS format were collected for the Zagros Mountains. To process the data the semi-automated method (Evans et al. 2009) was used to remove the noise and classify the objects. This semiautomated method allowed us to detect and interpret particular objects in the study area. The pre-processing technique has been applied to the point cloud data to achieve the certain level of quality data before it is used for tectonic geomorphology river mobility and landslide investigations.

The bare-earth (i.e. segregating objects such as trees from the surface and extracting the earth's surface) was extracted. This process has a direct impact on the quality of the DEM and tectonic geomorphology investigations. During last decades, various solutions and algorithms for the classification of the LiDAR data were published $[25,26]$. The method was based on the surface interpolation [27]. The DEM was calculated based on the entire point set by adapting the influence of the individual input points. 
The author used Hierarchical Robust Filtering (HRF) method and ArcGIS 10.2 software to develop the high-resolution DEMs of the study area. HRF method is originally designed for laser data in the vegetated and rugged topography areas such as Zagros Mountains. This algorithm is embedded in the SCOP++ software. The HRF is also called as robust interpolation method. HRF involves four processing approaches. They are (1) thin out, (2) filter, (3) interpolate, and (4) sort out. The thin out approach is a raster based thinning algorithm. It lays a grid over the complete data and selects one point for each cell. In the filter approach, a DEM is computed, but this time a weighting function. It is used to provide a low to high computational weighting for each cell. The weight function has a half of its maximum value ( $h$ is the half-width value) at $h$ above g. These values determine the steepness of the weight function at a particular point. The cut off refers to " $\mathrm{t}$ " in the right tail the weight function. As for the interpolation, a DEM is derived from the current data set by interpolation approach without differentiating data points. As for the sort out step, the author defined the distance from the calculated DEM by data points and three iterations. The classifying step has completed the filtering procedure. The major extension of the sort out step was to classify step.

\section{Digital Image Processing and River Profiles}

The digital image processing was applied on the ETM+ satellite image and the DEM for enhancing the structural features. The DEM and the satellite image were geologically interpreted using the techniques of raster elements (Lillesand and Kiefer [28]). Topography, erosion, sedimentation, vegetation, tone, slope, shape, and geomorphological features like water gaps, river terraces were the main elements for interpretation of the image and DEM. The structural geology map was developed, and the density of lineaments for each unit was interpreted to determine the tectonic activity. It also gave us an insight probability of landslides occurrence and river mobility from location to location in the Zagros Mountains. The interpretation for classification of the lineament density is as (a) high density, (b) moderate density, and (c) low density (Figure 5).

The text format of point clouds in the form of $\mathrm{x}, \mathrm{y}$, and $\mathrm{z}$, was introduced to the River Tools 3.0 software in a GIS environment to generate DEMs. The river profiles were digitally drawn on DEMs by using River Tools software and GIS techniques. The Karun and Dez River profiles were also interpreted on the basis of ground truth data, image elements and tectonic geomorphology behavior. The tectonic signatures found were introduced to the river profiles. Integration of satellite images and field data for structural geology, tectonics and geomorphology using geo-information technologies could improve the mapping process. It also highlighted places in the profiles where a river course crossed smaller tectonic features, such as lineaments and concealed faults, and also where a river cut directly across an anticline. It also enhanced the investigation of the landslide study and improved the previous studies [29-32] of landslides assessment in the Zagros Mountains.

\section{Results and Discussions}

In the ZFB, the author found that the River Dez is responded by landslides that are induced by the tectonic activities, and it keeps changing the direction of the river followed by structural features such as faults, folds, and lineaments. However, this study showed that LiDAR has a significant impact on the quality of tectonic geomorphology analysis for river mobility in Zagros Mountains, Iran. This study determined that the rivers Dez and Karun and their tributaries have responded in different ways to similar tectonic scenarios (generally NNE-SSW plate convergence producing mainly NW-SE trending anticlinal folds and thrust faults which follow the Zagros trend). The authors also found that the different formations dominating various type of rocks like limestone and evaporates in the Gachsaran Formation, shale of Aghajari Formation, marls of Kashkan Formation, Cretaceous calcareous (i.e., contact of the Imbricate Zone and Zagros Fold Belt with Sanandaj-Sirjan Zone) may approach the graded profile of the Dez River, and are associating with landslides. This study emphasized that the ZSB has deformed and developed landslides not only because of the tectonic processes and uplift but also because of rugged and immature topography.

The form of the rivers Dez and Karun and their drainages mainly relate to structural features such as folds, faults and lineaments. This study found various changes in the landscape due to the various and complex tectonic activities of the area. The author found that the erosion and sedimentation due to tectonic activity has changed the landscape of the Zagros Mountains in the study area. The geomorphology of the area is influenced by various processes and is currently being studied in more detail in lowland south-west Iran. The study indicated that the course of the River Dez crosses smaller tectonic features, such as lineaments and concealed faults mostly in the Tang-e-5, Tang-e-7, and Shahbazan areas, and that the course of the River Karun crosses them to the north of the Gotvand dam and near Ahwaz station in the lowlands of the study area. However, due to the high tectonic activities and the high erosion in Aghajari and Gachsaran Formations hazards process has accelerated susceptibility of rock falls and landslides in the Tang-e-5, Tang-e-7, and Shahbazan areas associated with the River Dez. This study also showed that the River Dez cuts directly across the Kabirkooh Anticline in and around the Tang-e-Fanni area north of Dezful. This complex process of tectonic, erosion, and sedimentation generates water gaps, knickpoints, meanders, oxbows and many other tectonic geomorphologic features in the study area.

The integration of LiDAR-derived DEM, satellite data, and several field visits indicated that the "Zagros deformation front", has probably migrated towards the south-west with time, particularly from the end of the Pliocene onwards. This means that there is an approximate relationship between space and time for rivers Dez and Karun in the Zagros Fold Belt and the Mesopotamian Foreland basin in south-west Iran. Towards the north-east, the 
fluvial geomorphology will be progressively less responsive to present-day tectonics (especially where a river has incised into a growing fold, thereby, effectively, "fixing" its course). In these areas, the author does not experience landslide hazards. However, whereas towards the south-west, the fluvial geomorphology will be progressively more responsive to more recent tectonics. Thus, it may influence and accelerate landslides process. Using the highresolution of DEMs and satellite image superimposed with the help of geospatial techniques in remote sensing and GIS environment software, a portion of the study area was on screen digitized and changes within the Late Quaternary were extracted (Figure 4).

In summary, this study determined that there are three classes of lineament density that are associating with influencing landslides. The areas with high lineament density are more susceptible to landslides. The author also found that there are a variety of tectonic influences on the rivers Dez and Karun in the Zagros Fold Belt (ZFB) and Mesopotamian Foreland Basin, lowland south-west Iran. The main effects of tectonics are probably those of localised changes in river course and plan form in response to the growth of the NWSE trending anticlinal folds, due to their considerable effects on local topography. Localised river course and plan form changes are also expected in response to all of the other tectonic features. Indeed, it may be possible to infer previously unknown tectonism from localised anomalous fluvial geomorphology, such as changes in channel sinuosity. Also, they may be good signatures to identify landslide locations. This may produce some useful contributions to tectonics, since landslides and earthquakes data may be incomplete and on industrial seismic section the youngest reflectors are usually not imaged.

This study showed that LiDAR has a significant improvement in tectonic geomorphology investigations and analysis as compared to the ortho photo World View 2 from the Digital Globe at https:// data.photosat.ca/. Because a DEM from the Digital Globe has elevation grid. This elevation grid is the tops of buildings and top of tree canopy in ortho photo World View 2 images.

\section{Conclusions and Recommendation}

This study concluded that in semi-arid foreland basin, the river response to structural uplift was greatly influenced by the location and timing of movement of the river channel relative to the location and timing of the uplift. In the ZFB, the author found that the River Dez is responded by tectonic associated with landslides, and it keeps changing the movement direction of the river followed by structural features such as faults, folds, and lineaments. The LiDARderived DEMs approach stressed that the high quality of ALS data allows improving the interpretational performance of tectonic geomorphology investigations because it provides surface detailed information as compared to the previous studies and traditional methods despite from limitations.

In general, tectonics probably promote river incision to the north-east of the "Zagros deformation front" and river aggradations to the south-west of it. These tectonic influences may have been similar throughout the Late Quaternary. However, with average uplift rates of the order of only about $1 \mathrm{~mm} /$ year [18] or $0.2 \mathrm{~mm} /$ year [33], it is apparent that these general effects have been largely masked by more prominent changes in other factors during about the last 18,000 years. Rather, it is the specific effects of tectonic structures (such as anticlinal folds) on the plan form geomorphology of the rivers (such as channel sinuosity) that are manifest. This study showed a method of improving understanding of the geo-information technologies in which the rivers Dez and Karun are impacted upon by significant changes of neo-tectonics during the Late Quaternary. It also showed how to improve tectonic geomorphology of river mobility investigation and landslides studies by using a high-resolution of DEMs by using ALS and TLS. This paper emphasized a methodology which integrates LiDAR, GIS, GPS, tectonic geomorphology associated with the ground truth data to study the tectonic signatures. The results to date ease the problem of tectonic targeting in the rivers Karun and Dez, showed the strong influences of neotectonics on the courses and plan forms of these two rivers from reach to regional scales, and showed that aspects of their fluvial geomorphology may relate to tectonic signatures. The details of these tectonic signatures in the ZFB, and lowlands of south-west Iran are currently being analysed and will be the subject of future published works.

Finally, the author recommend using the LiDAR-derived DEMs integrating with the satellite surveying images such as ortho photo World View 2 to improve the interpretation and investigation of landslides and river mobility.

\section{Acknowledgement}

The author used the high-resolution of LiDAR-derived DEM to improve tectonic geomorphology analysis, investigation, and interpretation of tectonic signatures to influencing landslides and river mobility. The LiDAR-derived DEMs are useful for tectonic geomorphology investigations, particularly when we acquire a high-resolution DEM.

\section{References}

1. Blum MD, Törnqvist TE (2000) Fluvial responses to climate and sea-level change: a review and look forward. Sedimentology 47(Suppl 1): 2-48.

2. Lang A, Bork HR, Mäckel R, Preston N, Wunderlich J, et al. (2003) Changes in sediment flux and storage within a fluvial system: some examples from the Rhine catchment. Hydrological Processes 17(3): 321-334.

3. Ali Syed Ahmad, Pirasteh Saied (2004) Geological application of Landsat Etm for mapping structural geology and interpretation: Aided by Remote sensing and GIS, International Journal of Remote Sensing 25(21): 47154727 .

4. Pirasteh Saied, Tripathi Kumar Nitin, Ayazi M Hasan (2006) Localizing Ground Water Potential Zones in Parts of Karst Pabdeh Anticline, Zagros Mountain, South-West Iran using Geospatial Techniques. International Journal of Geoinformatics 2(2): 35-42.

5. Pirasteh Saied, Jonathan Li, Michael Chapman (2017) Use of LiDARderived DEM and a Stream Length-gradient Index Approach to Investigation of Landslides in Zagros Mountains, Iran Geocarto International Journal. 
6. (2005) Iranian National Committee on Irrigation and Drainage (IRNCID) Directory and Country Profile-Iran. Web pages (9 in total) of the IRNCID.

7. Derron MH, Jaboyedoff M (2010) Preface to the special issue. In: LIDAR and DEM techniques for landslides monitoring and characterization. Nat Hazards Earth System Sciences 10: 1877-1879.

8. Lohani B, Mason DC (1998) Construction of a digital elevation model of the Holderness coast using the waterline method and airborne thematic mapper data. International Journal of Remote Sensing 20(3): 593-607.

9. Wehr A, Lohr U (1999) Airborne laser scanning an introduction and overview. ISPRS J Photogramm Remote Sens 54(2-3): 68-82.

10. Baltsavias EP (1999) Airbone laser scanning: basic relations and formulas. ISPRS J Photogrammetry Remote Sens 54(2-3): 199-214.

11. Lohani B, Singh R (2008) Effect of data density, scan angle, and flying height on the accuracy of building extraction using LiDAR data. Geo Carto International 23(2): 81-94.

12. Pirasteh S, Li J (2016) Landslides investigations from geo-informatics perspective: Quality, challenges, and recommendations. Geomatics, Natural Hazards and Risk 8(2): 448-465.

13. Pirasteh Saied, Jonathan Li, Michael Chapman (2017) Use of LiDARderived DEM and a Stream Length-gradient Index Approach to Investigation of Landslides in Zagros Mountains, Iran Geocarto International Journal.

14. Shan J, Toth K (2008) Topographic laser ranging and scanning: principles and processing. Taylor \& Francis Group, CRC Press, LLC, UK.

15. Prokop A, Panholzer H (2009) Assessing the capability of terrestrial laser scanning for monitoring slow moving landslides. Nat Hazards Earth System Science 9(6): 1921-1928.

16. Safe Land deliverable 4.1 (2010) Review of techniques for landslide detection, fast characterization, rapid mapping and long-term monitoring. In: Michoud C, Abella'n A, Derron MH, Jaboyedoff M (Eds) Safe Land European project.

17. Stocklin J (1984) Orogen and Tethys evolution in the Middle East, An appraisal of current concept. 27th IGC Colloquium 5, Suezach, Switzerland. 5.3ak, 1391.

18. Falcon NL (1974) Southern Iran: Zagros Mountains. In: Spencer, AM (Ed.) Mesozoic - Cenozoic Orogenic Belts: Data for Orogenic Studies. Edinburgh: Scottish Academic Press, Geological Society Special Publication No. 4: 199-211.

19. Colman Sadd SP (1978) Fold development in Zagros Simply Folded Belt, southwest, Iran. Bulletin American Association of Petroleum Geologist 62(6): 984-1003.

20. Pirasteh Saied, Ali Syed Ahmad (2005) Lithostratigraphic study from Dezful to Brojerd-Dorood areas SW Iran using digital topography, remote sensing and GIS. Indian Petroleum Geology Journal 13(1): 1-13.
21. Blanc EJ-P, Allen MB, Inger S, Hassani H (2003) Structural styles in the Zagros Simple Folded Zone, Iran. Journal of the Geological Society of London 160: 401-412.

22. Alavi M (1994) Tectonics of the Zagros orogenic belt of Iran: new data and interpretations. Tectonophysics 229(3-4): 211-238.

23. Berberian M (1995) Master "blind" thrust faults hidden under the Zagros folds: active basement tectonics and surface morphotectonics. Tectonophysics 241(3-4): 193-224.

24. Burbank DW, Anderson RS (2001) Tectonic geomorphology. Blackwell Science, Malden, USA and Abingdon, pp. 274.

25. Glenn Nancy F, Streutker David R, Chadwick D John, Thackray Glenn D, Dorsch Stephen J (2006) Analysis of LiDAR-derived topographic information for characterizing and differentiating landslide morphology and activity. Geomorphology 73(1-2): 131-148.

26. Su Cheng, Wang Lili, Wang Xizhi, Huang Zhicai, Zhang Xiaocan (2015) Mapping of rainfall-induced landslide susceptibility in Wencheng, China, using support vector machine. Nat Hazards 76(3): 1759-1779.

27. Pfeifer N, Kostli A, Kraus K (1998) Interpolation and filtering of laser scanner data implementation and first results. Remote Sensing and Spatial Information Sciences 32: part3/1, International Archives of Photogrammetry, Columbus, pp. 153-159.

28. Lillesand TM, Kiefer RW (2008) Remote sensing and image interpretation, $6^{\text {th }}$ edn. Wiley, New York, pp. 20-180.

29. Schulz William H (2007) Landslide susceptibility revealed by LIDAR imagery and historical records, Seattle, Washington. Engineering Geology 89(1-2): 67-87.

30. Rajabi AM, Mahdavifar MR, Khamehchiyan M (2011) A new empirical estimator of coseismic landslide displacement for Zagros Mountain region (Iran). Natural Hazards 59(2): 1189-1203.

31. Farrokhnia Alireza, Pirasteh Saied, Pradhan Biswajeet, Pourkermani Mohamad, Arian Mehrdad (2011) A recent scenario of mass wasting and its impact on the transportation in Alborz Mountains, Iran: Contribution from Geo information technology. Arabian Geosciences Journal 4: 13371349.

32. Siyahghalat Sajadi, Saraf Arun Kumar, Pradhan Biswajeet, Jebur Neamah Mustafa, Shafapour Tehrany Mahyat (2016) Rule based semi automated approach for the detection of landslides induced by 18 September 2011 Sikkim, Himalaya, earth quake using IRS LISS3 satellite images. Geomatics, Natural Hazards and Risk 7(1): 326-344.

33. Reyss JL, Pirazolli PA, Haghipour A, Hatté C, Fontugne M (1998) Quaternary marine terraces and tectonic uplift rates on the south coast of Iran. In: Stewart IS, Vita Finzi C (Eds.) Coastal Tectonics. Bath: The Geological Society, Geological Society Special Publication No. 146: 225237.
This work is licensed under Creative Commons Attribution 4.0 License

To Submit Your Article Click Here: $\quad$ Submit Article

DOI: 10.32474/TCEIA.2018.01.000122



